\title{
Analysis of Small Molecules by Ultra Thin- Layer Chromatography-Atmospheric Pressure Matrix-Assisted Laser Desorption/Ionization Mass Spectrometry
}

\author{
Piia K. Salo and Hannele Salomies \\ Faculty of Pharmacy, Division of Pharmaceutical Chemistry, University of Helsinki, Helsinki, Finland
}

Kirsi Harju and Raimo A. Ketola

Viikki Drug Discovery Technology Center, University of Helsinki, Helsinki, Finland

\section{Tapio Kotiaho}

Department of Chemistry, Laboratory of Analytical Chemistry and Viiki Drug Discovery Technology Center, University of Helsinki, Helsinki, Finland

\section{Jari Yli-Kauhaluoma and Risto Kostiainen}

Faculty of Pharmacy, Division of Pharmaceutical Chemistry and Viikki Drug Discovery Technology Center, University of Helsinki, Helsinki, Finland

\begin{abstract}
The feasibility of ultra thin-layer chromatography atmospheric pressure matrix-assisted laser desorption ionization mass spectrometry (UTLC-AP-MALDI-MS) has been studied in the analysis of small molecules. Because of a thinner adsorbent layer, the monolithic UTLC plates provide 10-100 times better sensitivity in MALDI analysis than conventional high performance thin-layer chromatography (HPTLC) plates. The limits of detection down to a low picomole range are demonstrated by UTLC-AP-MALDI-MS. Other advantages of UTLC over HPTLC include faster separations and lower solvent consumption. The performances of AP-MALDI-MS and vacuum MALDI-MS have been compared in the analysis of small drug molecules directly from the UTLC plates. The desorption from the irregular surface of UTLC plates with an external AP-MALDI ion source combined with an ion trap instrument provides clearly less variation in measurements of $\mathrm{m} / \mathrm{z}$ values when compared with a vacuum MALDI-time-of-flight (TOF) instrument. The performance of the UTLC-AP-MALDI-MS method has been applied successfully to the purity analysis of synthesis products produced by solid-phase parallel synthesis method. (J Am Soc Mass Spectrom 2005, 16, 906-915) () 2005 American Society for Mass Spectrometry
\end{abstract}

I $\mathrm{n}$ recent years, improvements in thin-layer chromatography (TLC) instrumentation and methods as well as the introduction of the high-performance thin-layer chromatography (HPTLC) has increased the use of this simple, inexpensive, and efficient method. TLC allows simultaneous analysis of many samples on one plate, the plates are disposable, and therefore memory effects can be avoided, solvent consumption is low, and a number of nondestructive detection methods with appropriate derivatization reagents can be used in sequence. The modern HPTLC technique, combined with automated sample application and densitometric

Published online April 20, 2005

Address reprint requests to Prof. Risto Kostiainen, Faculty of Pharmacy, Division of Pharmaceutical Chemistry, P.O. Box 56, FIN-00014 University of Helsinki, Helsinki, Finland. E-mail: risto.kostiainen@helsinki.fi scanning, has proven to be sensitive, reliable, and suitable for the qualitative and quantitative analysis of pharmaceutical, environmental, toxicological, forensic, and food samples [1-9].

The development of miniaturized ultra-thin-layer chromatography (UTLC) [10] in addition to the development of other miniaturized analytical methods [11] is currently a hot topic in analytical chemistry. The UTLC method combined with UV or diode-array detection (DAD) provides faster elution times (1-6 min), lower solvent consumption (1-4 ml), and lower detection limits than those obtained when using the conventional TLC or HPTLC methods [12]. However, the weakness of UTLC when compared with HPTLC is reduced resolution caused by shorter elution distances and a smaller overall specific adsorption surface area [12].

Several methods, such as ultraviolet/visible (UV/ 
VIS), fluorescence, DAD, mass spectrometry (MS), Fourier transform infrared (FTIR), and Raman spectroscopy have been applied for the in situ detection of analyte zones on a TLC plate [12-15], the most common of these being UV and fluorescence. In qualitative TLC, the identification of the compounds is based on either the color reactions of the separated sample zones or on the comparison of the $R_{F}$ values of the analyte and a standard compound after visualization under a UV lamp. Quantitative TLC measurements are performed by densitometric scanning using either one or several wavelengths in absorbance or fluorescence mode. With densitometric measurements the analytes are identified by their corrected $R_{F}$ values and by using UV/VIS-spectra of the analytes and standard compounds measured in situ. In those cases in which the standard compounds are not available (e.g., the screening of new natural agents or combinatorial chemistry samples), the identification of unknowns has to be performed using a specific technique, such as mass spectrometric detection.

The combination of TLC and MS has been a very active research area over the last few years [5-21]. TLC-MS has most frequently been performed as an off-line process in which the sample is scraped and extracted from the plate before MS analysis [5, 22, 23], or is analyzed as such with the use of various in situ techniques [15, 16, 19-21, 24-31], the most common of these being TLC-liquid secondary ion mass spectrometry (LSIMS), TLC-fast atom bombardment (FAB), TLC-matrix-assisted laser desorption/ionization (MALDI), and TLC-surface-assisted desorption/ionization (SALDI).

MALDI, as a simple and fast technique, has been found to be the most promising method for direct TLC-MS analysis [15, 16, 19, 24-29]. The operational parameters of TLC-MALDI-MS have been well characterized. For example, it has been observed that a lower analyte to matrix ratio for low mass molecules is needed compared to MALDI analysis of high mass molecules [26]. Different approaches on how to add the matrix have also been investigated, electrospraying the matrix on top of the separated analyte zones being one of the most promising techniques [26-29]. The use of different matrix compounds has also been compared [19, 20, 24-29]. Many of the matrices used in TLC-MALDI-MS cause interfering mass peaks at low mass numbers. However, it has been shown that the matrix background can be suppressed by using appropriate analyte-to-matrix molar ratio in MALDI measurements [23, 26, 32-35]. New potential matrices, producing low matrix background, have also been introduced [16, 20, 21, 27, 30, 31]. A disadvantage of the MALDI method has been the relatively poor repeatability in quantitative analysis. However, a recent study demonstrated good precision with an internal standard method [29] in which the internal standard was predeveloped over the plate. Furthermore, working with vacuum MALDI sources, as was done in all the TLC-MALDI papers published to date, makes the method somewhat risky since large amounts of chromatographic material are directly introduced inside the vacuum chamber of a mass spectrometer. This can be avoided by working with the recently introduced atmospheric pressure MALDI (AP-MALDI) [32, 36-38] source. Changing the sample plates is faster with AP-MALDI instruments than with vacuum MALDI instruments since pump down is not needed. Additionally, the ionization process in AP-MALDI compared with vacuum MALDI has been reported to be softer and therefore can produce more intact protonated molecule and less fragmentation than in vacuum MALDI [32].

In this study, we present a novel UTLC-APMALDI-MS method which was tentatively introduced for the first time in our earlier work [39]. UTLC and HPTLC methods using both the UV and APMALDI-MS detection, and UTLC combined with APand vacuum MALDI-MS, are compared in the analysis of small molecules. Commercial, pharmaceutically interesting compounds as well as heterocyclic 1,2,3triazoles produced by solid-phase combinatorial chemistry are used in the comparison.

\section{Experimental}

\section{Reagents}

In the experiments, two types of compound were used (Figure 1). The reference standards of midazolam, verapamil (as hydrochloride salt) and metoprolol (as tartrate salt) were obtained from Roche (Basel Switzerland), Sigma-Aldrich (Steinheim, Germany), and ICN Biomedicals (Aurora, $\mathrm{OH}$ ), respectively. Five other compounds, which all are 1,2,3-triazoles (Figure 1), were selected from a combinatorial library synthesized in our laboratory by the solid-phase method described by Harju et al. [40]. $\alpha$-Cyano-4-hydroxycinnamicëacid $(\alpha$-CHCA), used as a matrix compound for MALDI-MS analysis, was purchased from Fluka Chemie (Buchs, Switzerland). All organic solvents were of analytical or chromatographic grade. Ethyl acetate was purchased from Merck (Darmstadt, Germany), acetonitrile and dichloromethane from Rathburn (Walkerburn, Scotland), and $n$-hexane and methanol from J. T. Baker (Deventer, Holland). Trifluoroacetic acid, acetic acid, and $25 \%$ ammonia solution were from Acros Organics (Geel, Belgium), Rathburn (Walkerburn, Scotland), and Riedel-de Haën (Seelze, Germany), respectively.

\section{Sample and Matrix Solutions}

All stock solutions of compounds were prepared by dissolving a compound into a concentration of $1 \mathrm{mg} /$ $\mathrm{ml}$, triazole 1 and 2 with dichloromethane/methanol (50:50 vol/vol), triazole 3 and 4, and metoprolol with methanol, and midazolam and verapamil with acetonitrile. The working solutions of the compounds were prepared by diluting a stock solution with the same solvent used to prepare the stock solution. The stock 
Comp. Name (MW) and structure

1 Triazole 1 (229.3)

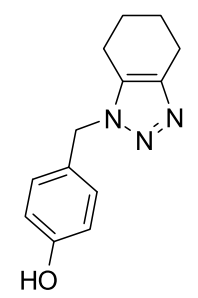

2

Triazole 2 (235.2)

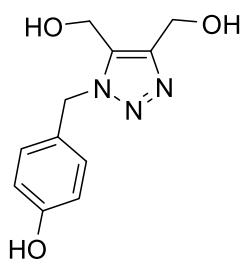

3

Triazole 3 (145.2)

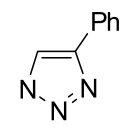

4

Triazole 4 (185.1)<smiles>CC(=O)c1n[nH]nc1C(C)=O</smiles>

5

Triazole 5 (175.2)

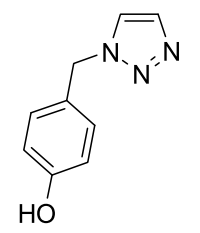

6

Midazolam (325.8)

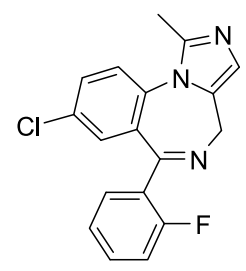

7

Verapamil (454.6)<smiles>COc1ccc(CCN(C)CCCC(C)(C(C)C)C(C)(C)c2ccc(OC)c(OC)c2)cc1OC</smiles>

8

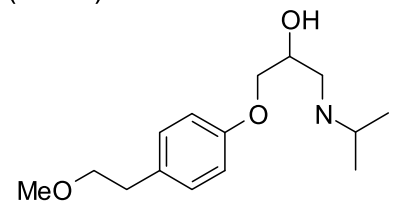

Figure 1. Structures and molecular weights (average masses) of the compounds used.

solution of the matrix $(13.3 \mathrm{mg} / \mathrm{ml})$ was prepared using the following method: $20 \mathrm{mg}$ of $\alpha$-CHCA was diluted with 2 parts of acetonitrile and 1 part of methanol containing $0.1 \%$ trifluoroacetic acid. The working solutions of the matrix were prepared by diluting the stock solution with acetonitrile.

\section{UTLC and HPTLC Method}

For planar chromatography, silica gel $60 \mathrm{~F}_{254}$ HPTLC plates (glass support) of $10 \times 10 \mathrm{~cm}$ (Merck) and monolithic UTLC plates (glass support) of $3.6 \times 6 \mathrm{~cm}$ (Merck) were used. The plates were prewashed once with acetonitrile before sample application. Sample solutions were sprayed as a thin rectangular band onto the adsorbent in amounts of 1 or $10 \mu \mathrm{l}$ with a Linomat IV (Camag, Muttenz, Switzerland) at a flow rate of $4 \mu \mathrm{l} / \mathrm{min}$ as 3 -mm-long bands with $4 \mathrm{~mm}$ spaces. The total amount of samples on the plate was between 1 pmol and $10 \mathrm{nmol}$.

The mobile phase composition was optimized with theëhelpëofëtheëPRISMAëmodelë[41-ï5].ëEthylëacetate$n$-hexane $(1: 2 \mathrm{vol} / \mathrm{vol})$ containing $2 \%$ acetic acid was used as the final mobile phase for triazoles, and ethyl acetate containing $0.5 \%$ ammonium hydroxide for drugs. The plates were eluted in a saturated chamber to the distance of $2 \mathrm{~cm}$ for UTLC and $5 \mathrm{~cm}$ for HPTLC. The elution time was 2-4 min for UTLC and 5-8 min for HPTLC. After elution, HPTLC plates were first detected visually under a UV lamp (Desaga, Heidelberg, Germany) and finally with a Camag TLC Scanner II (Muttenz, Switzerland) controlled by the CATS 3.17 program at $\lambda=222 \mathrm{~nm}$ for drugs and $228 \mathrm{~nm}$ for triazoles $\left(D_{2}\right.$ lamp). The UTLC plates could only be detected using a TLC Scanner II owing to the lack of a fluorescent indicator. The densitometric measurements were performed in absorption and reflection modes. In situ UV spectra of the compounds were measured at wavelength range of $190-450 \mathrm{~nm}$.

\section{MALDI Instrumentation}

The AP-MALDI mass spectrometry system consisted of an AP-MALDI ion source (Agilent Technologies, Germany) combined with an Esquire 3000plus ion trap instrument (Bruker Daltonics, Bremen, Germany). The AP-MALDI interface has been described in detail earlier byëDoroshenkoëetëal.ë[32].ëAfterëaddingëofëtheëmatrix, UTLC and HPTLC plates were attached to the face of an in-house-modified AP-MALDI target plate with double-sided conductive tape after cutting the plate to match the target plate. A nitrogen laser at $337 \mathrm{~nm}(10$ $\mathrm{Hz}$ ) was focused on the sample zone on a plate, the size ofëtheëlaserëspotëbeingë0.5ëmmë[32].ëTheëlaserëpulse energy was adjusted with an attenuator to 8.5 (arbitrary unit) providing an estimated pulse energy $264 \mu \mathrm{J}$ from the laser. The ions formed in the laser pulses were directed to the ion trap via extended capillary of the ion trap instrument. A potential of $2200 \mathrm{~V}$ was applied to 
Table 1. $R_{F}$ values and plate heights $(H)$ of the compounds studied by the UTLC and HPTLC methods with UVdensitometry

\begin{tabular}{lccccrr}
\hline & & \multicolumn{2}{c}{$\mathrm{R}_{\mathrm{F}}$} & & \multicolumn{2}{c}{$\mathrm{H}(\mu \mathrm{m})$} \\
\cline { 3 - 4 } \cline { 6 - 7 } Comp. & Name & UTLC & HPTLC & UTLC & HPTLC \\
\hline \hline 1 & Triazole 1 & 0.19 & 0.11 & & 328 & 125 \\
2 & Triazole 2 & 0.10 & 0.03 & & 184 & 445 \\
3 & Triazole 3 & 0.80 & 0.54 & 87 & 35 \\
4 & Triazole 4 & 0.50 & 0.22 & & 102 & 96 \\
6 & Midazolam & 0.88 & 0.22 & & 68 & 115 \\
7 & Verapamil & 0.97 & 0.24 & & 41 & 90 \\
8 & Metoprolol & 0.37 & 0.04 & 314 & 296 \\
\hline
\end{tabular}

the capillary. Nitrogen was used as a drying gas with a flow rate of $6 \mathrm{~L} / \mathrm{min}$ and a temperature of $150{ }^{\circ} \mathrm{C}$. The ion trap parameters were as follows: the accumulation time, $200 \mathrm{~ms}$, the "averages" were set at 10, and the "rolling averaging" was "off." The voltages of the skimmer and capillary exit were 34 and $160 \mathrm{~V}$, respectively. The mass spectra were recorded in the range of $\mathrm{m} / \mathrm{z}$ 100-500. For MS/MS measurements, the cut-off value was set to $m / z 100$ and the fragmentation amplitude to 2.0. Other parameters were the same as in the MS mode. The instrument was calibrated using external calibration method and calibration mixtures provided by the instrument manufacturer. The resolution was calculated to be about 950 within the measured mass range.

Vacuum MALDI measurements were performed using a Bruker Autoflex MALDI-time-of-flight (TOF) instrument (Bruker Daltonics) operating with a nitrogen laser at $337 \mathrm{~nm}(5 \mathrm{~Hz})$. The size of the laser spot was approximately 100-150 $\mu \mathrm{m}$ (private communication, Bruker Daltonics). After adding of the matrix, UTLC plates were attached to the face of an in-house-modified MALDI target plate with double-sided conductive tape after cutting the plate to match the target plate. MS instrument was operated in positive ion mode with the applied acceleration voltage of $20 \mathrm{kV}$. Attenuation value related to laser power in one pulse were $47 \%$ for drugs and $50 \%$ for triazoles. Averages of 50 pulses were recorded for MS spectra. The calibration was done by using $[\mathrm{M}+\mathrm{H}]^{+}\left(m / z\right.$ 190) and $[\mathrm{M}+\mathrm{Na}]^{+}(m / z$ 212) ions of the matrix as internal calibration points. The resolution was calculated to be about 1200 within the measured mass range.

\section{Results and Discussion}

\section{Mobile Phase and UV-Detection}

The preoptimization of the mobile phase with UTLC plates was carried out with the help of PRISMA modelë41-ë5]ëusingëUVëdensitometricëdetection.ëThe optimal solvent composition for triazoles (Compounds 1-5) was ethyl acetate- $n$-hexane (1:2) containing $2 \%$ acetic acid, and for the drug substances (Compoundsë6ë8) ëethylëacetateëcontainingë0.5\%ёammonium hydroxide. With these eluents, the $R_{F}$ values of the compounds studied were between 0.1 and 0.97 with UTLC and between 0.03 and 0.54 with HPTLC plates,ë (Tableë 1)ë providingë goodë separationë efficiency. The $R_{F}$ values obtained by UTLC are higher because the total surface area is smaller, i.e., the adsorbent layer is thinner and the specific surface area is smaller in UTLC $\left(10 \mu \mathrm{m}\right.$ and about $\left.350 \mathrm{~m}^{2} / \mathrm{g}\right)$ than in HPTLC plates $\left(0.2 \mathrm{~mm}\right.$ and about $\left.500 \mathrm{~m}^{2} / \mathrm{g}\right)$ [12].ëFurthermore, ëheëplateëheightsë(H)ëwereënëmost of the cases higher with UTLC plates than with HPTLCëplatesë(Tableë1).ëTheëelutionëtimeëwasëabout two times shorter with UTLC (2-4 min) than with HPTLC (5-8 $\mathrm{min}$ ) and the solvent consumption in the elution of one UTLC plate was $3 \mathrm{ml}$, which was about three times less than with HPTLC. All these UTLC results are parallel to the results reported earlier by HauckëandëSchulzë[12].

Theërelativeëstandardëdeviationsë(RSD)ëofëtheëR valuesëwereëbetweenël.7ëndë3.1\%(̈Tableè)ëndicating good repeatability of the separation with UTLC. The quantitative repeatability of the UTLC-UV measured as peak heights or areas were acceptable, RSDs being belowë9\%ё(Tableë2).ëTheëlimitsëofëdetectionë(LODs) measured using a UV densitometer $(\mathrm{S} / \mathrm{N}=3)$ were about 1-10 times lower with UTLC than HPTLC for mostëofëtheëcompoundsëstudiedë(Tableë3).ëAlthough

Table 2. Repeatability of UTLC-UV and UTLC-AP-MALDI-MS methods $(n=5)$ as mean, standard deviation $( \pm$ SD), and relative standard deviation (RSD \%). Sample amount on plate was $0.1 \mathrm{nmol}$ and matrix amount was $10 \mathrm{nmol}$

\begin{tabular}{|c|c|c|c|c|}
\hline \multirow[b]{2}{*}{ Compound } & \multicolumn{3}{|c|}{ UV } & \multirow{2}{*}{$\frac{\text { AP-MALDI-MS }}{\text { Abs. abund. of }[\mathrm{M}+\mathrm{H}]^{+}}$} \\
\hline & $\mathrm{R}_{\mathrm{F}}$ & Peak area & Peak height & \\
\hline \multicolumn{5}{|l|}{ Triazole 1} \\
\hline Mean $\pm S D$ & $0.29 \pm 0.005$ & $185.3 \pm 15.3$ & $11.7 \pm 0.4$ & $540 \pm 136$ \\
\hline RSD \% & 1.7 & 8.3 & 3.8 & 25.1 \\
\hline \multicolumn{5}{|l|}{ Midazolam } \\
\hline Mean \pm SD & $0.53 \pm 0.01$ & $480.0 \pm 29.2$ & $22.6 \pm 0.8$ & $1830 \pm 399$ \\
\hline RSD \% & 1.9 & 6.0 & 3.7 & 21.8 \\
\hline \multicolumn{5}{|l|}{ Metoprolol } \\
\hline Mean \pm SD & $0.16 \pm 0.005$ & $110.4 \pm 6.9$ & $7.4 \pm 0.4$ & $975 \pm 216$ \\
\hline RSD \% & 3.1 & 6.2 & 5.7 & 22.1 \\
\hline
\end{tabular}


Table 3. Limits of detection (LODs) of UTLC/HPTLC-UV and UTLC/HPTLC-AP- and vacuum MALDI-MS (S/N = 3)

\begin{tabular}{|c|c|c|c|c|c|c|}
\hline \multirow[b]{2}{*}{ Compound } & \multicolumn{6}{|c|}{ Method } \\
\hline & $\begin{array}{l}\text { UV non-eluted } \\
\text { (pmol) }\end{array}$ & $\begin{array}{l}\text { UV eluted } \\
\text { (pmol) }\end{array}$ & $\begin{array}{c}\text { AP-MALDI-MS } \\
\text { non-eluted } \\
\text { (pmol) }\end{array}$ & $\begin{array}{l}\text { AP-MALDI-MS } \\
\text { eluted (pmol) }\end{array}$ & $\begin{array}{c}\text { Vacuum } \\
\text { MALDI-MS } \\
\text { non-eluted } \\
\text { (pmol) }\end{array}$ & $\begin{array}{c}\text { Vacuum } \\
\text { MALDI-MS } \\
\text { eluted } \\
\text { (pmol) } \\
\end{array}$ \\
\hline \multicolumn{7}{|l|}{ Triazole 1} \\
\hline UTLC & 38 & 69 & 4 & 12.5 & 10 & 33 \\
\hline HPTLC & 23 & 79 & 280 & 500 & - & \\
\hline \multicolumn{7}{|l|}{ Triazole 2} \\
\hline UTLC & 88 & 154 & 85 & 100 & 90 & \\
\hline HPTLC & 25 & 75 & 750 & 2140 & - & \\
\hline \multicolumn{7}{|l|}{ Triazole 3} \\
\hline UTLC & 33 & 84 & 30 & 300 & 16 & \\
\hline HPTLC & 68 & 539 & 500 & 750 & - & \\
\hline \multicolumn{7}{|l|}{ Triazole 4} \\
\hline UTLC & 42 & 79 & 100 & 400 & 90 & \\
\hline HPTLC & 266 & 819 & 6700 & $>10000$ & - & \\
\hline \multicolumn{7}{|l|}{ Midazolam } \\
\hline UTLC & 1 & 25 & 0.5 & 4.8 & 4 & 5 \\
\hline HPTLC & 4 & 326 & 30 & 300 & - & \\
\hline \multicolumn{7}{|l|}{ Verapamil } \\
\hline UTLC & 7 & 66 & 0.5 & 1.3 & 3 & \\
\hline HPTLC & 9 & 622 & 22 & 300 & - & \\
\hline \multicolumn{7}{|l|}{ Metoprolol } \\
\hline UTLC & 49 & 54 & 4 & 6.4 & 4 & \\
\hline HPTLC & 25 & 345 & 31 & 600 & - & \\
\hline
\end{tabular}

UTLC-UV provides a fast and repeatable analysis method, the specificity of the method is not good enough for detailed structural characterization of the compounds. Therefore, the capability of APMALDI-MS for the identification of compounds directly from UTLC and HPTLC plates was studied.

\section{UTLC/HPTLC-MALDI-MS}

For MALDI-MS analysis, the use of a matrix was required since the ionization efficiency of the compounds studied from the UTLC and HPTLC without the matrix was very poor. $\alpha$-Cyano-4-hydroxycinnamic acid ( $\alpha$-CHCA) was selected to be as a matrix compound, since it provided good ionization efficiency for the compounds studied. The matrix was sprayed over the sample zone with a TLC applicator device (Linomat IV), by which the matrix could be deposited precisely in the center of the sample zone in the form of narrow bands. The spreading of the sample zone was not visually observable. The application time for the matrix onto one sample zone of the UTLC plate was only $15 \mathrm{~s}$ ( $1 \mu \mathrm{l}$ applied with a flow rate of $4 \mu \mathrm{l} / \mathrm{min}$ ) providing a very rapid preparation of the UTLC plates for MALDI-MS analysis. In conclusion, the Linomat spray-on technique provides the same advantages obtained by using the electrospraying technique reported byëMowthorpeëetëal.ë[26].

The matrix amount in MALDI-MS and TLCMALDI-MS has been shown to have a significant effect on the sensitivity, repeatability, and matrix background
[23,ë26,ë33-35,ë46,ë47].ëTheëeffectëofëtheëmatrixëamount on sensitivity and selectivity was studied by applying 1 nmol of midazolam and triazole 1 onto the UTLC and HPTLC plates. The concentration of the $\alpha$-CHCA solution was varied in the optimization experiments between $190 \mathrm{ng} / \mu \mathrm{l}$ and $13.3 \mu \mathrm{g} / \mu \mathrm{l}$, thus the total amount of $\alpha$-CHCA on the plate varied between 1-1000 nmol. The optimal matrix amount was $10 \mathrm{nmol}$ for UTLC (about $2.66 \mathrm{nmol} / \mathrm{mm}^{2}$ ) and $100 \mathrm{nmol}$ for HPTLC (about $22.2 \mathrm{nmol} / \mathrm{mm}^{2}$ ). The lower amount of matrix reduced sensitivity and the higher amount caused increased matrix background and therefore decreased selectivity.

The effect of the dry gas $\left(\mathrm{N}_{2}\right)$ temperature on the ionization with AP-MALDI-MS was tested because it has been reported that the temperature affects the analyte-matrix dissociation process in AP-MALDIMS, i.e., at low temperatures, formation of the analyte/matrix clusters/dimers has been observed, whereas high temperature can cause fragmentation of molecularëionëofëtheëanalytesë[32].ëTheëtestsëwere made between $100-250{ }^{\circ} \mathrm{C}$ using $1 \mathrm{nmol}$ of triazole 1 on the UTLC plate. The absolute abundance of the protonated molecule doubled when the temperature was raised from 100 to $150{ }^{\circ} \mathrm{C}$. The rise in temperature from 150 to $250{ }^{\circ} \mathrm{C}$ increased fragmentation and reduced the abundance of the protonated molecule. The temperature of dry gas had no clear effect on the specificity since no additional peaks appeared, and the ratio of the relative abundances of the matrix ions and the analyte ions did not change significantly 
(a)

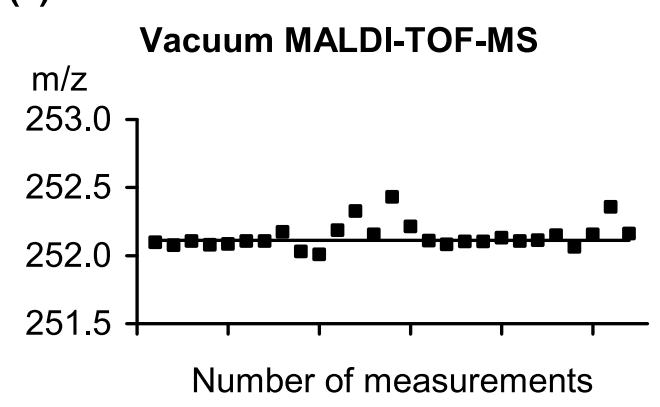

(b)

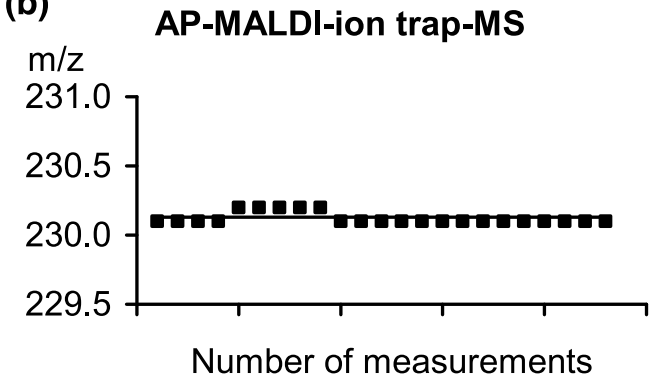

Figure 2. Replicate measurements of (a) triazole $1[\mathrm{M}+\mathrm{Na}]^{+}$ ions $(\mathrm{m} / \mathrm{z}=252.111)$ by UTLC-vacuum MALDI-MS (internal calibration mode); $n=27$, and (b) triazole $1[\mathrm{M}+\mathrm{H}]^{+}$ions $(\mathrm{m} / z=$ 230.129) by UTLC-AP-MALDI-MS (external calibration mode); $n$ $=23$. $($ filled square $)=$ measured mass, $($ line $)=$ calculated mass.

when the temperature was raised from 100 to $250^{\circ} \mathrm{C}$. The optimal temperature was $150^{\circ} \mathrm{C}$, which was selected for the further studies.

The target plate of the AP-MALDI system used in this study was maintained in a fixed position mode. With this mode the matrix disturbances were strong during the first laser pulses, but the relative abundances of the analyte ions compared with the matrix ions increased along with the number of pulses. The same observation was made with vacuum MALDI-MS. This suggests that the analyte molecules were not diffused thoroughly into the matrix and the concentration of the analytes was higher on the surface of the UTLC plate than on the surface of the matrix. When using the UTLC plate with a matrix amount of $10 \mathrm{nmol}$, the signal lasted for about $30 \mathrm{~s}$ in the fixed mode. By increasing the matrix amount, the signal lasted longer and, for example, with $100 \mathrm{nmol}$ the analyte ions were observed for a few min. The long-lasting signal allows sequential mass analysis including, for example, optimization of operation parameters, measurements of MS, and different kinds of MS/MS spectra in positive and negative ion mode from sample zone.

Figureë2ëshowsëtheëvariationëofë $m / z$ valuesëfor triazole 1 measured from different sample zones on theëUTLCëplatesëbyëvacuumëMALDI-TOF-MSëFigure 2a)ëusingënternalëcalibration,ëndëbyëAP-MALDI-ion trap-MSë(Figureë2b)ëusingëexternalëcalibration.ëVariation in $m / z$ values was clearly less with AP-MALDIion trap-MS $( \pm 0.08 \mathrm{u})$ than with vacuum MALDITOF-MS $( \pm 0.32 \mathrm{u})$. These results are in accordance to the earlier studies in which it has been shown that irregular surface materials, such as polymer membranes and TLC plates, can lead to decreased mass accuracyëbyëvacuumëMALDI-TOF-MSë[48,ë49].ëHowever, AP-MALDI-ion trap-MS provides the coupling of UTLC without compromising in mass accuracy, taking into account that the used ion trap is not a high resolution instrument. Parallel results have been obtained by TLC-MALDI-Fourier transform (FT) MS usingëanëxternalëionësourceë[50].

\section{Spectra}

The AP- and vacuum MALDI mass spectra of the compounds studied were measured by applying $1 \mathrm{~mol}$ of the analyte and $10 \mathrm{nmol}$ of the matrix on the UTLC plateë(Tableë4).ëTheëmeasuredëmassëspectraëproduced by both sources exhibited an abundant protonated molecule and only the compounds including the hydroxy group (triazole 1 and 2, and metoprolol) produced an abundant sodium adduct ion. The spectra of triazoles 1 and 2 and verapamil also showed some fragment ions. The appearance of $[\mathrm{M}+\mathrm{Na}]^{+}$in addition to formation of the fragment ions was somewhat stronger with vacuum MALDI-MS than with AP-

Table 4. Main analyte ions in mass spectra measured by UTLC-AP- and UTLC vacuum MALDI-MS before elution. Sample amount was $1 \mathrm{nmol}$ and matrix amount $10 \mathrm{nmol}$

\begin{tabular}{|c|c|c|c|c|c|c|c|}
\hline \multicolumn{4}{|c|}{ UTLC-AP-MALDI-MS } & \multicolumn{4}{|c|}{ UTLC-Vacuum-MALDI-MS } \\
\hline Comp. & {$[\mathrm{M}+\mathrm{H}]^{+}$} & $\begin{array}{c}\mathrm{m} / \mathrm{z} \text { (rel. abund) } \\
{[\mathrm{M}+\mathrm{Na}]^{+}}\end{array}$ & Other ions & Comp. & {$[\mathrm{M}+\mathrm{H}]^{+}$} & $\begin{array}{c}\mathrm{m} / \mathrm{z} \text { (rel. abund) } \\
{[\mathrm{M}+\mathrm{Na}]^{+}}\end{array}$ & Other ions \\
\hline Triazole 1 & $230(100)$ & $252(25)$ & $124^{\mathrm{a}}(36)$ & Triazole 1 & $230(48)$ & $252(100)$ & $124^{\mathrm{a}}(83), 107^{\mathrm{b}}(10)$ \\
\hline Triazole 2 & $236(100)$ & $258(79)$ & $130^{c}(84)$ & Triazole 2 & $236(-)$ & $258(100)$ & $130^{c}(30), 107^{b}(20)$ \\
\hline Triazole 3 & $146(100)$ & & & Triazole 3 & $146(100)$ & & \\
\hline Triazole 4 & $186(50)$ & $208(100)$ & & Triazole 4 & $186(50)$ & $208(100)$ & \\
\hline Midazolam & $326(100)$ & - & - & Midazolam & $326(100)$ & - & - \\
\hline Verapamil & $455(100)$ & - & $303(12)$ & Verapamil & $455(100)$ & - & $303(63)$ \\
\hline Metoprolol & $268(100)$ & $290(15)$ & & Metoprolol & $268(100)$ & $290(8)$ & \\
\hline
\end{tabular}

${ }^{\mathrm{a}} \mathrm{m} / \mathrm{z} 124=\left[\mathrm{C}_{6} \mathrm{~N}_{3} \mathrm{H}_{10}\right]^{+},{ }^{\mathrm{b}} 107=\left[\mathrm{CH}_{2} \mathrm{C}_{6} \mathrm{H}_{4} \mathrm{OH}\right]^{+},{ }^{\mathrm{c}} 130=\left[\mathrm{C}_{4} \mathrm{~N}_{3} \mathrm{O}_{2} \mathrm{H}_{8}\right]^{+}$ 
(a)

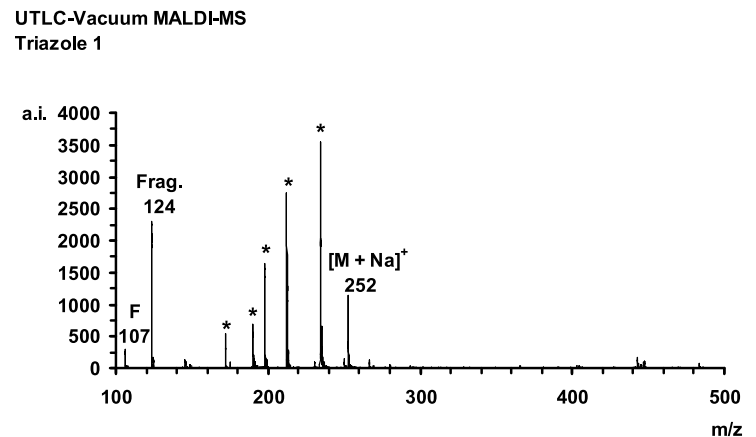

(b)

UTLC-AP-MALDI-MS

Triazole 1

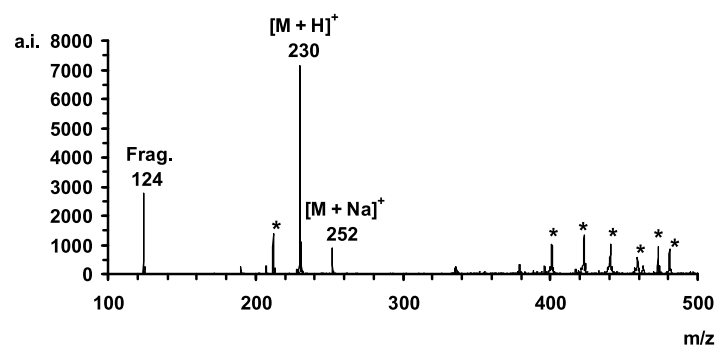

(d)

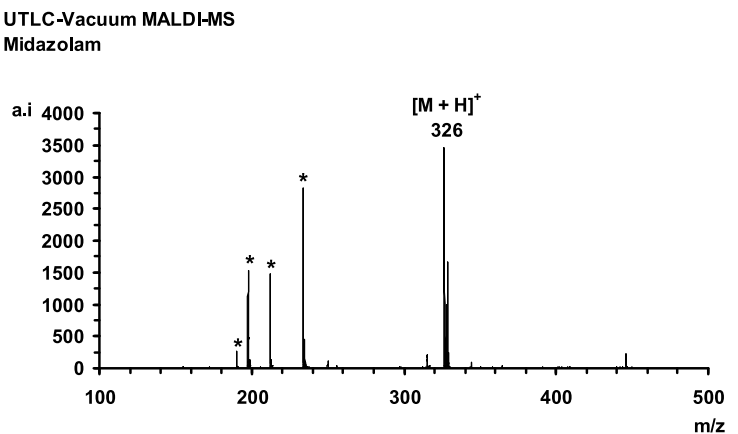

(e)

UTLC-AP-MALDI-MS

Midazolam

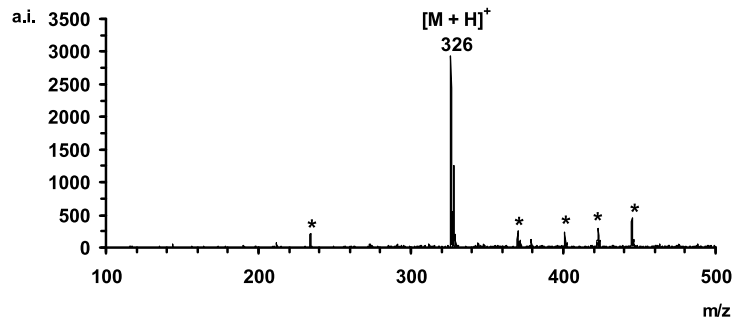

(c)

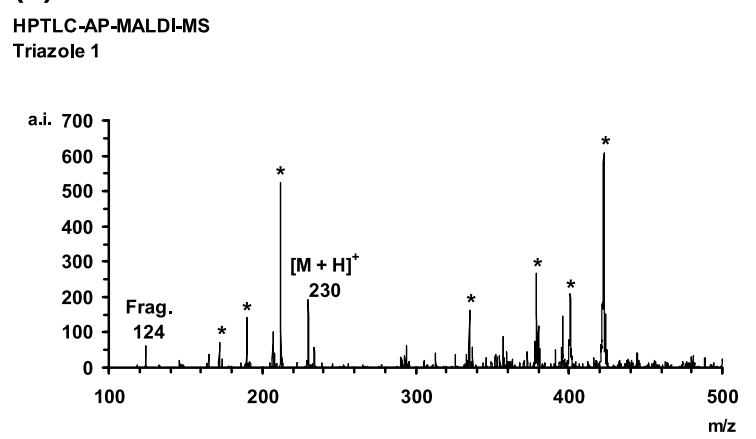

Figure 3. Mass spectra of triazole $1(\mathbf{a}-\mathbf{c})$ and midazolam (d) and (e) measured by UTLC-vacuum MALDI-MS (a) and (d), UTLC-AP-MALDI-MS (b) and (e), and HPTLC-AP-MALDI-MS (c). Sample amounts are $1 \mathrm{nmol}$ and matrix ( $\alpha$-CHCA) amount was $10 \mathrm{nmol}$ (UTLC) and $100 \mathrm{nmol}$ (HPTLC). The mainëmatrixëionsëareëmarkedëwithëanëasterisk.ëForëanalyteëfragmentëonsë(F),ëseeėTableë4.

MALDI-MS, which indicates a more energetic ionization process of vacuum MALDI-MS under operational conditions used in this study since $[\mathrm{M}+\mathrm{Na}]^{+}$ions are often more stable than $[\mathrm{M}+\mathrm{H}]^{+}$. Also, the stabilization of the protonated molecule by collisional cooling was more efficient in AP-MALDI-MS than in vacuum MALDI-MS.

Figureë3ëillustratesëasëanëexampleëtheëAP-ëand vacuum MALDI mass spectra of triazole 1 and midazolam $(1 \mathrm{nmol})$ measured from the eluted UTLC plate and AP-MALDI mass spectrum of triazole $1(1 \mathrm{nmol})$ from the eluted HPTLC plate. In vacuum MALDI-MS, the abundant matrix background ions (marked as an asterisk) were observed below $\mathrm{m} / \mathrm{z} 250$. AP-MALDI mass spectra showed the same matrix ions at a mass range below $\mathrm{m} / \mathrm{z} 250$ but also matrix dimers, which were not observed with vacuum MALDI-MS. The dimers are rapidly stabilized by collisional cooling in AP-MALDI-MS and they can be transferred into the ion trap. The collisional cooling in vacuum MALDI-MS is significantly less than in APMALDI-MS leading to dissociation of the dimers in the vacuum MALDI-TOF experiments. However, all the analyte ions were visible using both methods. The matrix background is significantly lower with midazolamë(Figureë3e)ëthanëwithëtriazoleë1ë(Figureë3b). This might be because the physical and chemical properties, such as proton affinity, hydrophobicity, absorbtivity at $337 \mathrm{~nm}$ of midazolam, are more favorable for efficient ionization than those of triazole 1. 
(a)

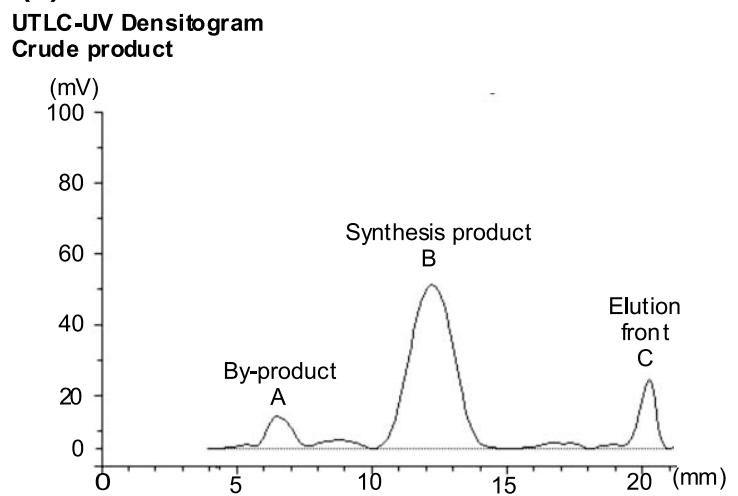

(b)

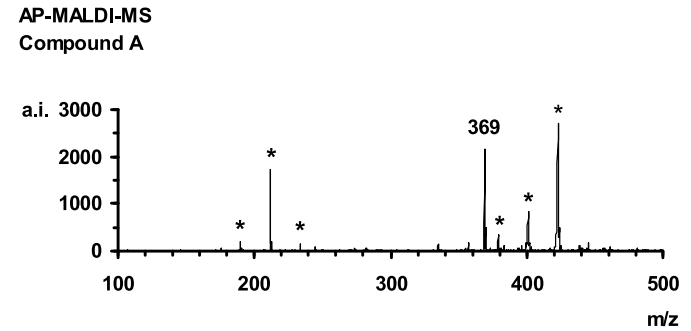

(c)

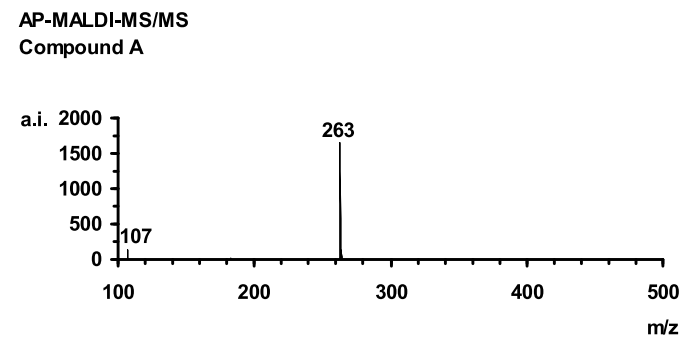

(d)

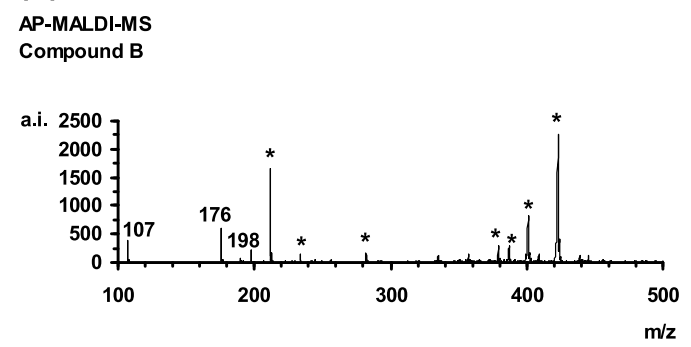

(e)

AP-MALDI-MS/MS

Compound B

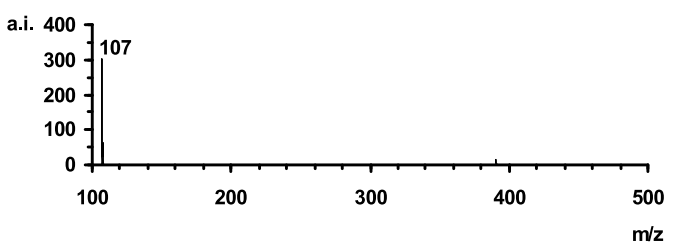

On the other hand, the extraction efficiency from the inner parts of the silica layer to the matrix during the addition of the matrix solution might be better with midazolam than with triazole 1 . The comparison betweenë UTLC-ë (Figureë 3b)ë andë HPTLC-APMALDI-MSë(Figureë3c)ëspectraëofëtriazoleëlëndicates that the matrix disturbances are less with the UTLC than with the HPTLC plate. This is because the optimal matrix amount with UTLC plates $(10 \mathrm{nmol})$ is ten times less than with HPTLC plates $(100 \mathrm{nmol})$.

\section{Limit of Detection and Repeatability}

Thedimitsëfë̈letectionëLODs)ëTableè)ëwithäUTC-APMALDI-MS (S/N = 3) after elution were 10-400 pmol for triazoles (1-4), and 1-7 pmol for the drug substances (6-8). The LODs with HPTLC-AP-MALDI-MS were $500-10,000$ pmol for triazoles (1-4) and 300-600 pmol for drug substances (6-8). These results show that with AP-MALDI-MS UTLC plates provide about 10-100 times better sensitivity than HPTLC plates. This holds also when the measurements were performed from the application zone (i.e., before elution). The better sensitivity with UTLC plates can be attributed to a thinner adsorbent layer of the UTLC plates. It follows that the number of molecules per surface area is significantly higher on the UTLC plate than on the HPTLC plate. Furthermore, with UTLC plates the analyte molecules are extracted from the inner parts of the adsorbent onto the surface more efficiently than with HPTLC. The laser pulse is capable of ionizing the compounds efficiently only from the surface of the adsorbent. The spreading of the zone during the elution reduced sensitivity, as the LODs measured from the application zone were about 2-10 times lower than those measured after elution. This suggests that the sample application with a narrower band might lead to lower LODs especially with the UTLC method. The LODs obtained with APMALDI-MS and vacuum MALDI-MS were mostly at the same level.

Quantitative repeatability of the UTLC-AP-MALDI-MS was studied on five different plates after elution by using 0.1 nmol of triazole 1, midazolam, and metoprolol, and $10 \mathrm{nmol}$ of the matrix. The relative standard deviations were about 22-25\%ë(Tableë2)ëshowingëthatëtheëmethodëisëlikelyëtoëbe more suitable for semi-quantitative than for analysis in which high quantitative accuracy is required. Nevertheless, accurate quantitative results can be obtained using UV densitometry.

Figure 4. The identification of synthesis product (triazole 5) and by-product in crude product. (a) UTLC-UV densitogram of a synthesis sample and (b-e) AP-MALDI-MS spectra of the separated compounds; (b) MS spectrum of Compound A (by-product), (c) MS/MS spectrum of ion $\mathrm{m} / \mathrm{z} 369$ of Compound A, (d) MS spectrum of Compound B $\left(m / z\right.$ 176, $m / z$ 198, and $m / z 107$ are $[\mathrm{M}+\mathrm{H}]^{+},[\mathrm{M}+$ $\mathrm{Na}]^{+}$, and fragment ion $\left[\mathrm{CH}_{2} \mathrm{C}_{6} \mathrm{H}_{4} \mathrm{OH}\right]^{+}$of the synthesis product, respectively, (e) MS/MS spectrum of ion $m / z 176$ of Compound $\mathrm{B}$. 


\section{Application}

The UTLC-AP-MALDI-MS method was applied to the identification of the synthesis product (triazole $5, \mathrm{mw}$ 175.2) and possible by-products in a crude product. The compounds were separated using ethyl acetate- $n$ hexane $1: 2$ containing $2 \%$ acetic acid as an eluent (Figureë4).ëTheëUVëdensitogramëclearlyëshowsëtwo peaks with $R_{\mathrm{Fëv}}$ valuesëofë0.10ë(A)ëandë0.46ë(B)ënëFigure 4a.ëTheëAP-MALDI-MSëspectrumëofësynthesisëproduct (PeakëB,ëFigureë4d)ërevealsëanëabundantëprotonated molecule of triazole $5(\mathrm{~m} / \mathrm{z} 176)$, which produces in MS/MSë analysisë (Figureë 4e)ë aë productë ion $\left[\mathrm{CH}_{2} \mathrm{C}_{6} \mathrm{H}_{4} \mathrm{OH}\right]^{+}(\mathrm{m} / \mathrm{z} 107)$ confirming that the product is triazole 5. The ion $\mathrm{m} / \mathrm{z} 107$ is a common fragment ion for triazoles containing the phenolic functionality. The MS spectrumëofëby-productë(PeakëA,ëFigureë4b)ëshowsëan extraordinary ion at $m / z 369$, which does not exist in the spectrum of the matrix. The product ion spectrum of ion m/z 369ë(Figureë4c)ëshowedëanëonëatëm/z 107ëwhichëis also recognized in the product ion spectrum of triazole 5. This suggests that Peak A represents a synthesis by-product. After identification of the synthesis product with AP-MALDI-MS, the purity percentage of triazole 5 was calculated to be $80 \%$ in a crude product based on UV densitometry measurement.

\section{Conclusions}

We have reported herein the feasibility of a novel UTLC-AP-MALDI-MS method for the analysis of small drug molecules. The UTLC method has been compared with the HPTLC method with UV and AP-MALDI-MS detection and UTLC-AP-MALDI-MS has been compared with UTLC-vacuum MALDI-MS. The UTLC-APMALDI-MS analysis of crude synthesis sample produced by combinatorial chemistry has also been applied. The advantages of UTLC over HPTLC include faster separations and reduced solvent consumption. The use of MS provides enhanced specificity over UV detection and UTLC-AP-MALDI-MS significantly improved sensitivity when compared with HPTLC-APMALDI-MS. The applicability of UTLC-AP-MALDI-MS has been shown to be good enough for the identification of small drug molecules in relatively simple samples in MS mode. In more complex samples, the use of MS/MS is necessary. In conclusion, UTLC-AP-MALDI-MS provides improvements to the present (HP)TLC-vacuum MALDI-MS methods, preserving at the same time many of the advantages of the TLC, such as fast and parallel analysis, a disposable stationary phase that avoids memory effects, and the possibility to use other analytical techniques before MALDI-MS analysis.

\section{Acknowledgments}

The authors gratefully acknowledge C. Sauber (Ph.D.) and F. Mandel (Ph.D.) for technical support, and Agilent Technologies for providing the AP-MALDI ion source. They also thank K.
Vuorensola (Ph.D.), P. Östman (M.Sc.), and T. Rantanen (M.Sc.) for helpful discussions and technical assistance in MALDI experiments, and M. Baumann (Dos.) for providing MS instruments used in this study. The financial support of the National Technology Agency of Finland (TEKES) is gratefully acknowledged.

\section{References}

1. Hahn-Deinstrop, E. Stationary Phases, Sorbents. J. Planar Chromatogr. 1992, 5, 57-61.

2. Jaenchen, D. E. Thin-Layer (Planar) Chromatography. In Handbook of Instrumental Techniques for Analytical Chemistry; Settle, F., Ed.; Prentice Hall: New York, NY 1997; p 221-239.

3. Poole, C. F. Planar Chromatography at the Turn of the Century. J. Chromatogr. A 1999, 856, 399-427.

4. Renger, B. Benchmarking HPLC and HPTLC in Pharmaceutical Analysis. J. Planar Chromatogr. 1999, 12, 58-62.

5. Salo, P. K.; Pertovaara, A. M.; Salo, V.-M. A.; Salomies, H. E. M.; Kostiainen, R. K. High-Performance Thin-Layer Chromatography Method for Assessment of the Quality of Combinatorial Libraries, and Comparison with Liquid Chromatography-Ultraviolet-Mass Spectrometry. J. Comb. Chem. 2003, 5, 223-232.

6. Sherma, J. Planar Chromatography. Anal. Chem. 2000, 72, 9R-25R.

7. Kalász, H.; Báthori, M. Pharmaceutical Applications of TLC. LC-GC Eur. 2001, 14, 311-321.

8. Jork, H. Advances in Thin Layer Chromatography: Part 1. Int. Lab. 1993, 23, 18-22.

9. Weins, C.; Hauck, H. E. Advances and Developments in Thin Layer Chromatography. LC-GC Int. 1996, 9, 710-717.

10. Hauck, H. E; Bund, O.; Fischer, M.; Schulz, M. Ultra-Thin Layer Chromatography (UTLC) - A New Dimension in ThinLayer Chromatography. J. Planar Chromatogr. 2001, 14, 234236.

11. Huikko, K.; Kostiainen, R.; Kotiaho, T. Introduction to MicroAnalytical Systems: Bioanalytical and Pharmaceutical Applications. Eur. J. Pharm. Sci. 2003, 20, 149-171.

12. Hauck, H. E; Schulz, M. Ultrathin-Layer Chromatography. J. Chromatogr. Sci. 2002, 40, 1-3.

13. Somsen, G. W.; Morden, W.; Wilson, I. D. Planar Chromatography Coupled with Spectroscopic Techniques. J. Chromatogr. A 1995, 703, 613-665.

14. Busch, K. L. Coupling Thin Layer Chromatography with Mass Spectrometry. J. Planar Chromatogr. 1992, 5, 72-79.

15. Wilson, I. D. The State of the Art in Thin-Layer Chromatography-Mass Spectrometry: A Critical Appraisal. J. Chromatogr. A 1999, 856, 429-442.

16. Cohen, L. H; Gusev, A. I. Small Molecule Analysis by MALDI Mass Spectrometry. Anal. Bioanal. Chem. 2002, 373, 571-586.

17. Gusev, A. I. Interfacing Matrix-Assisted Laser Desorption/ Ionization Mass Spectrometry with Column and Planar Separations. Fresenius J. Anal. Chem. 2000, 266, 691-700.

18. Crecelius, A.; Clench, M. R.; Richards, D. S.TLC-MALDI in Pharmaceutical Analysis. LC-GC Eur. 2003, 16, 225-229.

19. Mehl, J. T.; Hercules, D. M. Direct TLC-MALDI Coupling Using a Hybrid Plate. Anal. Chem. 2000, 72, 68-73.

20. Santos, L. S.; Haddad, R.; Höehr, N. F.; Pilli, R. A.; Eberlin, M. N. Fast Screening of Low Molecular Weight Compounds by Thin-Layer Chromatography and "On-Spot" MALDI-TOF Mass Spectrometry. Anal. Chem. 2004, 76, 2144-2147.

21. Wu, J.-Y.; Chen, Y.-C. A Novel Approach of Combining Thin-Layer Chromatography with Surface-Assisted Laser Desorption/Ionization (SALDI) Time-of-Flight Mass Spectrometry. J. Mass Spectrom. 2002, 37, 85-90. 
22. Anderson, R. M.; Busch, K. L. Thin-Layer Chromatography Coupled with Mass Spectrometry: Interfaces to Electrospray Ionization. J. Planar Chromatogr. 1998, 11, 336-341.

23. St. Hilaire, P. M.; Cipolla, L.; Tedebark, U.; Meldal, M. Analysis of Organic Reactions by Thin Layer Chromatography Combined with Matrix-Assisted Laser Desorption/Ionization Time-of-Flight Mass Spectrometry. Rapid Commun. Mass Spectrom. 1998, 12, 1475-1484.

24. Gusev, A. I.; Proctor, A.; Rabinovich, Y. I.; Hercules, D. M. Thin-Layer Chromatography Combined with Matrix-Assisted Laser Desorption/Ionization Mass Spectrometry. Anal. Chem. 1995, 67, 1805-1814.

25. Gusev, A. I.; Vasseur, O. J.; Proctor, A.; Sharkey, A. G.; Hercules, D. M. Imaging of Thin-Layer Chromatograms Using Matrix-Assisted Laser Desorption/Ionization Mass Spectrometry. Anal. Chem. 1995, 67, 4565-4570.

26. Mowthorpe, S.; Clench, M. R.; Crecelius, A.; Richards, D. S.; Parr, V.; Tetler, L. W. Matrix-Assisted Laser Desorption/ Ionization Time-of-Flight/Thin Layer Chromatography/Mass Spectrometry-A Rapid Method for Impurity Testing. Rapid Commun. Mass Spectrom. 1999, 13, 264-270.

27. Crecelius, A.; Clench, M. R.; Richards, D. S.; Parr, V. ThinLayer Chromatography-Matrix-Assisted Laser Desorption Ionization-Time-of-Flight Mass Spectrometry Using Particle Suspension Matrices. J. Chromatogr. A 2002, 958, 249-260.

28. Crecelius, A.; Clench, M. R.; Richards, D. S.; Evason, D.; Parr, V. Thin-Layer Chromatography-Postsource-Decay MatrixAssisted Laser Desorption/Ionization Time-of-Flight Mass Spectrometry of Small Drug Molecules. J. Chromatogr. Sci. 2002, 40, 614-620.

29. Crecelius, A.; Clench, M. R.; Richards, D. S.; Parr, V. Quantitative Determination of Piroxicam by TLC-MALDI TOF MS. J. Pharm. Biomed. Anal. 2004, 35, 31-39.

30. Chen, Y.-C.; Shiea, J.; Sunner, J. Thin-Layer ChromatographyMass Spectrometry Using Activated Carbon, Surface-Assisted Laser Desorption/Ionization. J. Chromatogr. A 1998, 826, 77-86.

31. Chen, Y-C. In Situ Determination of Organic Reaction Products by Combining Thin Layer Chromatography with SurfaceAssisted Laser Desorption/Ionization Time-of-Flight Mass Spectrometry. Rapid Commun. Mass Spectrom. 1999, 13, 821825.

32. Doroshenko, V. M.; Laiko, V. V.; Taranenko, N. I.; Berkout, V. D.; Lee, H. S. Recent Developments in Atmospheric Pressure MALDI Mass Spectrometry. Int. J. Mass Spectrom. 2002, 221, 39-58.

33. Knochenmuss, R.; Dubois, F.; Dale, M.; Zenobi, R. The Matrix Suppression Effect in Matrix-Assisted Laser Desorption/Ionization: Application to Negative Ions and Further Characteristics. Rapid Commun. Mass Spectrom. 1996, 10, 871-877.

34. Knochenmuss, R.; Karbach, V.; Wiesli, U.; Breuker, K.; Zenobi, R. The Matrix Suppression Effect and Ionization Mechanisms in Matrix-Assisted Laser Desorption/Ionization. Rapid Commun. Mass Spectrom. 1998, 12, 529-534.

35. McCombie, G.; Knochenmuss, R. Small-Molecule MALDI Using the Matrix Suppression Effect to Reduce or Eliminate Matrix Background Interferences. Anal. Chem. 2004, 76, 49904997.

36. Laiko, V. V.; Baldwin, M. A.; Burlingame, A. L. Atmospheric Pressure Matrix-Assisted Laser Desorption/Ionization Mass Spectrometry. Anal. Chem. 2000, 72, 652-657.
37. Laiko, V. V.; Moyer, S. C.; Cotter, R. J. Atmospheric Pressure MALDI/Ion Trap Mass Spectrometry. Anal. Chem. 2000, 72, 5239-5243.

38. Tan, P. V.; Laiko, V. V.; Doroshenko, V. M. Atmospheric Pressure MALDI with Pulsed Dynamic Focusing for HighEfficiency Transmission of Ions into a Mass Spectrometer. Anal. Chem. 2004, 76, 2462-2469.

39. Salo, P.; Salomies, H.; Östman, P.; Huikko, K.; Kotiaho, T.; Ketola, R.; Kostiainen, R. Ultra-Thin-Layer ChromatographyMatrix-Assisted Laser Desorption/Ionization Mass Spectrometry-A New Possibility for Drug Analysis? In Advances in Mass Spectrometry, Vol. XVI; Ashcroft, A. E.; Brenton, G.; Monagham, J. J., Eds.; Elsevier B. V.: Netherlands, 2004; CD-ROM Supplement.

40. Harju, K.; Vahermo, M.; Mutikainen, I.; Yli-Kauhaluoma, J. Solid-Phase Synthesis of 1,2,3-Triazoles via 1,3-Dipolar Cycloaddition. J. Comb. Chem. 2003, 5, 826-833.

41. Nyiredy, S.; Meier, B.; Erdelmeier, C. A. J.; Sticher, O. "PRISMA": A Geometrical Design for Solvent Optimization in HPLC. J. HRC-CC 1985, 8, 186-189.

42. Nyiredy, S.; Meier, B.; Erdelmeier, C. A. J.; Sticher, O. "PRISMA": Ein Modell zur Optimierung der Mobilen Phase für die Dünnschichtchromatographie, Vorgestellt Anhand Verschiedener Naturstofftrennungen. Planta Med. 1985, 51, 241-246.

43. Nyiredy, S.; Dallenbach-Tölke, K.; Sticher, O. The "PRISMA" Optimization System in Planar Chromatography. J. Planar Chromatogr. 1988, 4, 336-342.

44. Nyiredy, S.; Dallenbach-Tölke, K.; Sticher, O. Correlation and Prediction of the $\mathrm{k}^{\prime}$ Values for Mobile Phase Optimization in HPLC. J. Liq. Chromatogr. 1989, 12, 95-116.

45. Nyiredy, S. Planar Chromatographic Method Development Using the PRISMA Optimization System and Flow Charts. J. Chromatogr. Sci. 2002, 40, 1-11.

46. Duncan M. W.; Matanovic, G.; Cerpa-Poljak, A. Quantitative Analysis of Low Molecular Weight Compounds of Biological Interest by Matrix-Assisted Laser Desorption Ionization. Rapid Commun. Mass Spectom. 1993, 7, 1090-1094.

47. Goheen, S. C.; Wahl, W. L.; Campbell, J. A.; Hess, W. P. Mass Spectrometry of Low Molecular Mass Solids by MatrixAssisted Laser Desorption/Ionization. J. Mass Spectrom. 1997, $32,820-828$

48. McComb, M. E.; Olenschuk, R. D.; Manley, D. M.; Donald, L.; Chow, A.; O’Neil, J. D. J.; Ens, W.; Standing, K. G.; Perreault, H. Use of a Nonporous Polyurethane Membrane as a Sample Support for Matrix-assisted Laser Desortion/Ionization Timeof-Flight Mass Spectrometry of Peptides and Proteins. Rapid Commun. Mass Spectom. 1997, 11, 1716-1722.

49. Guittard, J.; Hronowski, X. L.; Costello, C. E. Direct MatrixAssisted Laser Desorption/Ionization Mass Spectrometric Analysis of Glycosphingolipids on Thin Layer Chromatographic Plates and Transfer Membranes. Rapid Commun. Mass Spectom. 1999, 13, 1838-1849.

50. Ivleva, V. B.; Elkin, Y. N.; Budnik, B. A.; Moyer, S. C.; O'Connor, P. B.; Costello, C. E. Coupling Thin-Layer Chromatography with Vibrational Cooling Matrix-Assisted Laser Desorption/Ionization Fourier Transform Mass Spectrometry for the Analysis of Ganglioside Mixtures. Anal. Chem. 2004, 76, 6484-6491. 